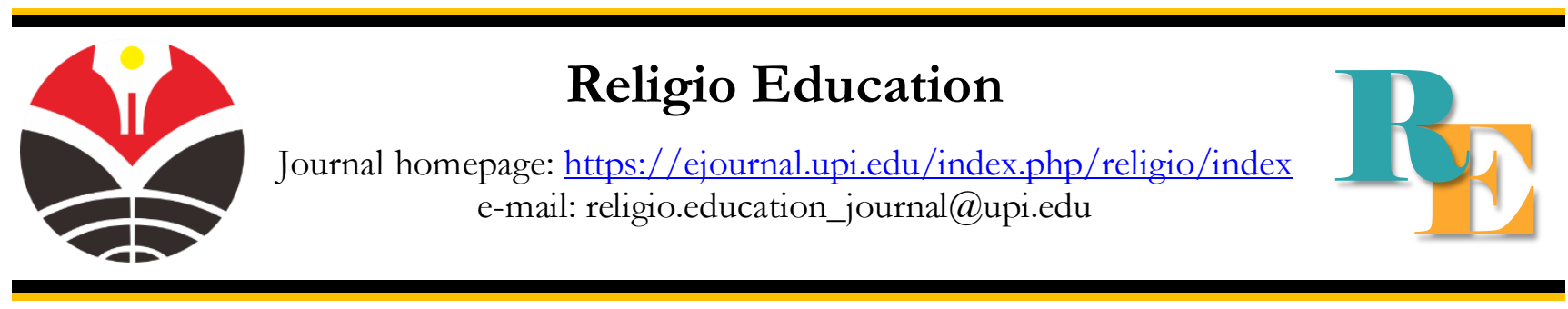

\title{
PHYSICS OF QUR'AN: ISLAMIZING THE SCIENCE AND ITS CONTRIBUTION TOWARDS HUMANITY
}

\author{
Dawam Multazamy Rohmatulloh* \\ Universiteit Utrecht, Heidelberglaan, the Netherlands \\ d.m.rohmatulloh@uu.nl
}

Arik Dwijayanto

Institut Agama Islam Sunan Giri Ponorogo, East Java, Indonesia arikdj99@gmail.com

*Correspondence: d.m.rohmatulloh@uu.nl

\section{A b s t r a c t s}

Physics is a fundamental science in the development of science and technology in the modern world. Physics studies the various forms of structure and character of natural objects. Thus, mastery of physics is one of the activities desired by Allah Swt. This article is made so that at least the Muslim community can realize the urgency of physics. In this study, we use the type/approach of research in the form of Library Research. The data that we obtain and process is data that comes from manuscripts or texts from similar previous studies. From this research, we conclude that the Qur'an is a way of life for all mankind. The Qur'an is like a miniature of the universe that contains all disciplines of science and is a means of solving all problems throughout human life. Besides that, physics has a very large and significant function and role in the existence of mankind. Also, the role of this physical science can ease the difficulties experienced by lightening the work of humans is not difficult.
Article Info

Article History:

Received 17 Juni 2021

Revised 21 Agustus 2021

Accepted 12 Oktober 2021

Available online 15 November 2021

\section{Keyword:}

Muslim Community;

Physics;

Science;

Technology.

\section{Introduction}

Physics is a fundamental science in the development of science and technology in the modern world. Physics studies about various forms of structure and character of natural objects. Thus, mastery of physics is one of the activities desired by Allah Swt (Bakuwa, 2013). In studying physics, the first thing to emphasize is measurement so that the basic quantities used in other scientific disciplines are obtained. In addition, in physics, simple phenomena such as the movement of matter are studied which must be discussed in other disciplines. Therefore, it cannot be denied that physics is the basic foundation in other modern scientific disciplines.

Starting from the enlightenment period in the 17 th century, western society began to realize the importance of scientific discussions and thoughts. This is evidenced by the development of technology in every aspect of human life and is the axis of world technological development. The development of a very massive science was started by Sir Isaac Newton who 
put forward the theory of motion and gravity. The theory can accurately predict the motion of simple matter to very large materials such as planets, meteors, and stars. Several decades later, on the other hand, James Watt succeeded in developing a steam engine that was ready and could be used. From the steam engine, industrial activities and transportation developed rapidly so that the industrial revolution began in Europe and its colonies. In physics, this era is known as the era of classical physics. Several centuries later, precisely in the 20th century, physics underwent a revolution from the era of classical physics to the era of modern physics. The study of modern physics cannot be explained by classical physics concepts, so in the early 20th century a German physicist named Albert Einstein published the theory of relativity which revolutionized the world of science. In this era, science and technology are the main reasons for changes in every aspect of human life (Parhan \& Kurniawan, 2020).

It is common knowledge that technological developments revolutionize industrial activities and industrial activities change the social conditions of society. The foundation of industrial activity is knowledge and technology. As an example in the food industry, initially almost all industrial processes were carried out manually by humans with the help of simple tools. With the increase in knowledge and technology in the food industry, several activities such as milling and packaging can be carried out by machines so that the work becomes more effective and efficient. On the other hand, knowledge and technology are also developing in the military industry so that the creation of weapons that have higher destructive power and destructive power. Therefore, it is undeniable that industrial activities can change the social conditions of society for the better or for the worse. Developing industrial activities can open up new job opportunities for the community but can create gaps for the less educated people.

In discussing the development of science and technology, the discussion seems to focus on Europe and America, but in fact the Islamic world has been the axis in the development of science and technology. At the time of the golden age of Islam around the 8th century to the 14th century, a scientist named Abu Ali al-Hasan bin al-Hasan bin al-Haitsam or Ibn al-Haitsam contributed greatly to the field of modern optics. In addition, he is known as the "Father of the modern scientific method" because of his role in processing and obtaining data. Scientists from the west follow the development of science knowledge and technology that developed in the Middle East region and continued it in the following centuries. until tit is undeniable that by being axis in the development of science and technology, can bring Islam to its golden age.

So this article is made so that at least the Muslim community can realize the urgency of physics. In this article will be given some of the relationship of physics with the Koran as the main way of life of a Muslim. This is because we know that danger is the backbone of technological development, physics can reach all aspects of human life. Technological progress is currently growing rapidly and is used as a starting point measure the progress of a nation. Muslims must be able to follow every existing developments so as not to become a people who are left behind, especially related to his duties as caliph on earth (Bakuwa, 2013). However, even now technological developments are not in the Muslim community so that the Muslim community is less able to compete in this aspect. One of the reasons is negative stereotypes in people's minds towards physics that can hinder the development of physics in today's Muslim society.

\section{Method}

In this study, we use a research type/approach in the form of a literature study (Library Research). Literature study is a series of activities related to the method of collecting library data, reading and taking notes and processing research materials. The data we obtain and process is data that comes from manuscripts or texts from similar previous studies. 


\section{Results and Discussion}

Physics as a branch of science is based on the thought of the Qur'an which is the basis of science. Not only the truth from a scientific point of view, but the understanding of physics should be understood in detail so that the truth can be studied in a real and universal way. This shows that there is a relationship between science and Islam that can be run simultaneously (Wati et al., 2021).

Physics is a very useful subject in life. Physics subject not only aims to equip students with knowledge but also aims to create students who glorify the greatness of God. The study of the theory of physics has been previously explained in the Qur'an and vice versa the truth of the verses of the Qur'an can be proven by the theory of physics. The link between the Koran and Physics can be proven through the verses of the Kauniyah. Kauniyah verse is a verse of the Koran that contains the greatness of the universe and all its contents (Laurenty et al., 2018).

Based on that, if students already have an attitude like happy and interested in taking the time towards learning physics, then will then settle down and continue his career in Physics also. Interested to continue career in the field of Physics can not be separated from how much large the individual has belief that a career in physics is one of the wishes for his future (Putra et al., 2019).

Integration is the process of combining certain values with other concepts so that they become a coherent and inseparable whole or the process of assimilation to become a unified whole. In this context, physics material will be combined with Qur'anic verses as the highest source of knowledge in Islamic education so that it becomes a blend of mathematics and religion. Kuntowijoyo in Fathul Mufid states that the essence of the integration of science is an effort to unite (not just combine) God's revelation and the findings of the human mind (rational sciences), not to exclude God (secularism) or isolate humans (other wordly asceticism). This integration model is to make the Qur'an and Sunnah as a grand theory of knowledge. So that the verses of Kauniyyah and Qawliyyah can be used. The integration referred to here is related to efforts to integrate general science with Islam without having to eliminate the uniqueness between the two sciences, in the Qur'an, there are many verses that explain the concepts of physics (Huda \& Mutia, 2017).

\section{Quranic Verses about Optics and Light}

If we talk about optics, of course, it can't be separated from light. Optical instruments always work with the role of light. We can observe together, in people who suffer from farsighted eye defects (hypermetropia). For nearsighted people, of course they really need the role of seeing aids in the form of glasses. However, not all glasses with any lens can be used, but especially for glasses with convex (positive) lenses. When people who are farsighted see objects at normal reading distances, the image of the object will fall behind the retina. To make the image of objects fall on the retina, the patient is assisted by using convex (positive) lenses. With the help of positive-lens glasses, the image of objects will fall right on the retina.

Meanwhile, nearsighted people have a far point that is much closer than the far point of the normal eye and the near point is shorter than the near point of the normal eye. If a myopic eye sees an object at infinity, the image of the object falls in front of the retina. This occurs because the lens of the eye cannot flatten properly as needed. Myopia sufferers really need a concave lens so that the image falls in front of the retina and objects can be seen clearly.

Light is energy in the form of visible electromagnetic waves with a wavelength of about 380-750 nm. Light is an electromagnetic wave (does not require a medium) to propagate, so light can propagate without the need for a medium.

Optical instruments are devices that use lenses and require light. The eye is a natural optical instrument. Our eyes have a very limited ability to see, that is, they cannot see clearly 
small objects, objects that are very far away and cannot record what they see properly. Therefore, our eyes must be assisted with artificial optical devices such as cameras, loupe, microscopes, and binoculars. Utilization of the concept of physics in the field of optics is also widely used by humans. An example of the use of the field of optics is the use of mirrors and lenses. The mirrors used include rearview mirrors, makeup mirrors, OHP, flashlight reflectors, motorcycle reflectors, car reflectors, and light collectors on microscopes. The use of lenses includes: loupes, telescopes, microscopes, glasses, OHP, projectors, cameras (Sutrisno, 1979).

The working principle of the mirror is the reflection or reflection of light. Rays that come into the mirror will be reflected back. The formation of an image on a mirror takes advantage of the special rays on the mirror. Concave and convex mirrors have different special rays. The following is an explanation of reflection in a mirror. We can see objects caused by two things, first, objects can emit light or the object is a light source, and the second is that the object reflects light from the light source so that our eyes can catch the reflected light and we can see the object. In Surah An-Nur verse 35 Allah Swt says:

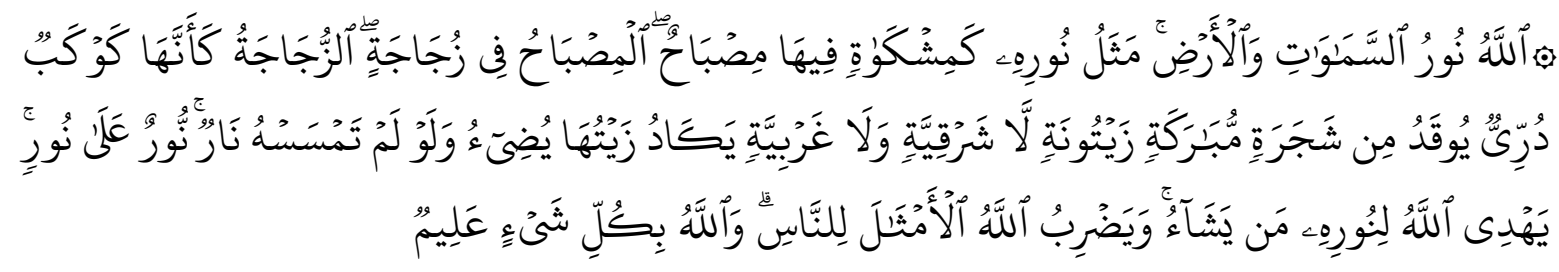

Meaning: "Allah (Giver) light (to) the heavens and the earth. The parable of Allah's light is like an impenetrable hole, in which is a large lamp. The lamp is in the glass (and) the glass is like a star (which shines) like pearls, which are lit with oil from a blessed tree, (ie) an olive tree that grows neither in the east (something) nor in the west. (him), whose oil (only) is almost illuminating, even though the fire does not touch it. Light upon light (in layers), Allah guides to His light whom He wills, and Allah sets forth parables for mankind, and Allah is Knower of all things. (Surat an-Nur: 35).

The verse above explains to humans that light objects can be seen because they are hit by light, then the light is reflected, so that we can see objects around us. What if God didn't create the sun? Of course the universe would be pitch black. Physically, Allah illuminates the earth and the sky with the sun. The sun has an average distance of 149.6 million kilometers from the earth. There is one implicit indication of the verse, namely sunlight can reach the earth's surface, one of the properties of light, where light can propagate without a medium (in outer space there is no air/vacuum). With a very long distance, sunlight can reach the earth's surface at the speed of light of $3 \times 10^{8} \mathrm{~m} / \mathrm{s}$.

\section{Quranic Verses about Matter and Its Changes}

Matter is anything that has mass and occupies space (has volume). Everything in the universe, including the human body, is matter. Matter exists in 3 forms: liquid, solid and gas. Material change is a change in the nature of a substance or material into another substance, whether it is a new substance or not (Abdullah, 2016). In discussing matter and its changes, it cannot be separated from the kinds of substances that consist of solid, liquid and gas. Regarding this matter, it is not forgotten that physics is a science that studies real events that are closely related to everyday life.

Like the following, of course we are familiar with detergents and stains on clothes, why can detergents remove stains on clothes? It can not be separated from the concept of matter and regarding the form of this substance, in discussing the form of matter there is of course a 
force of attraction for molecules. Due to the attraction of these mini molecules, detergents can lift stains on clothes.

Soaps and detergents can reduce the effect of surface tension on the water. The surface tension in pure water is very high, so that the dirt on the clothes is still attached to the clothes. If during the washing process, detergent is given pure water, the surface tension of the water in the small holes formed by the fibers and the clothes is reduced by the detergent, so that dirt can be released from the fiber holes in the clothes. So that with detergent the dirt that sticks to the clothes can be removed. The substances that can reduce the surface tension in the liquid are called surfactants.

So it can be concluded that matter is anything that has mass and occupies space. A material can undergo changes, namely physical changes and chemical changes. Physical changes are changes that do not produce new substances, while chemical changes are changes that produce new substances. Changes in matter involve the properties of matter, for example, physical changes involve the physical properties of a material, while chemical changes involve the chemical properties of a material (Tippler, 1998).

To make it easier to study a material in nature, it is necessary to classify it. Classification of matter based on state can be divided into solids, liquids, and gases. While the classification of matter based on its components can be divided into single substances and mixtures. In Surah Ar-Rum verse 48 Allah says:

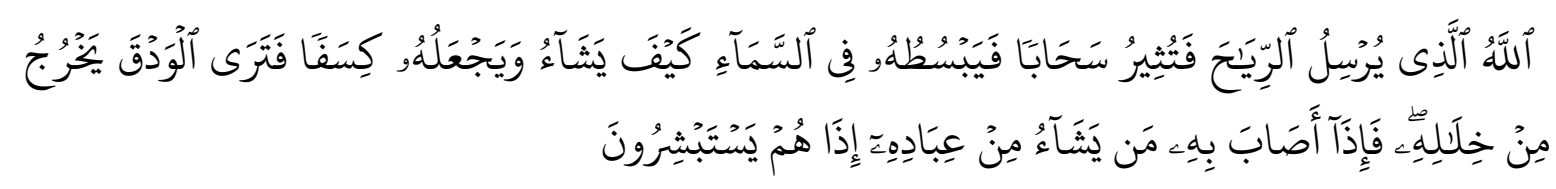

Meaning: "Allah, it is He who sends the wind, then the wind moves the clouds and Allah spreads them in the sky as He wills, and makes them lumpy; Then you see rain coming out of its crevices, so when it rains on His servants as He wills, suddenly they will be happy." (Surat Ar-Rum: 48). In Surah Al-An'am verse 6 Allah Swt says:

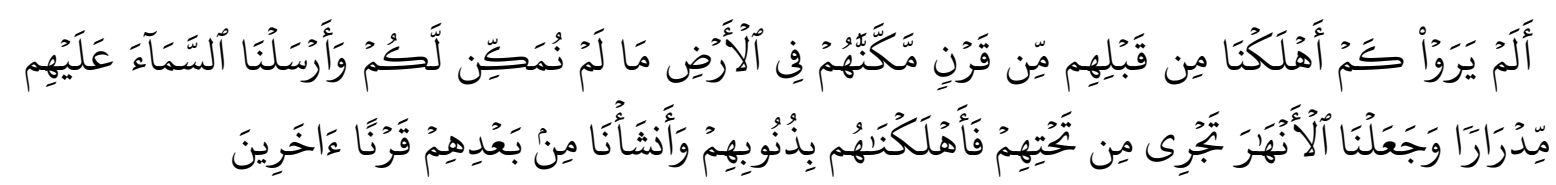

Meaning: "Have they not noticed how many generations We destroyed before them, even though (that generation) We had established their position on the earth, namely a firmness that We had not given you, and We poured down heavy rain on them and We made rivers flow under them, then We destroyed them for their own sins, and We created after them another generation." (Surat al-An'am: 6).

The verse above explains to humans about matter and its changes, namely the first stage that it is Allah who sends the wind. Water particles form clouds by collecting water vapor. The second stage, then the wind stirs up the clouds and Allah spreads them in the sky as He wills, and becomes lumpy. Clouds are formed from water vapor that condenses around salt crystals or dust particles in the air. The third stage, then you see rain coming out of the cracks, then when it rains it falls. The water particles surrounding the salt crystals and the dust particles thicken and form raindrops. So the droplets become heavier than air, leave the clouds and begin to fall to the ground as rain. 


\section{Quranic Verses about Measurement}

It is not uncommon to hear the word measurement. Because every human must have measured about an object. The unit of measurement that is recognized throughout the world has certain standards and has been determined through international agreements so that it can be used as a comparison in measurement and is fixed wherever we are.

Basically measuring is comparing something with something that has a certain similar quantity that is used as a unit. So that in everyday life, humans definitely need measuring tools, because with measuring instruments accuracy and accuracy of measurements can be achieved. Usually measuring tools are used in the fields of education, work, industry, research and so on (Ediyanto et al., 2019). The following are clearer details about the benefits of measuring tools in everyday life: First, Ruler: The accuracy of measurement using a ruler or ruler is half the value of the smallest scale. In every measurement using a ruler, keep the observer's eye position perpendicular to the scale to be measured. This is to avoid visual errors (parallax), which occurs when reading the scale of a measuring instrument because the position of the observer's eye is not right. Second, Rollmeter: this type of meter is used by builders or road width gauges because of the large measurement range, using this rollmeter to measure tables, buildings and roads will be easier and more accurate than using a ruler which only has a maximum value of $30 \mathrm{~cm}$. The accuracy of measurement with a rollmeter is the same as that of a ruler, which is $0.5 \mathrm{~mm}$. This meter material is usually made of plastic or a thin metal plate so that it can be rolled up and practically carried everywhere. Third caliper: a tool used to measure the length, thickness, depth of the hole, and the outer diameter and inner diameter of an object with an accuracy limit of 0.1 $\mathrm{mm}$, for example the diameter of rings, bottle holes, coins or paralon pipes and the length of small blocks, screws or nail. The caliper has two jaws, namely a fixed jaw and a sliding or sliding jaw. The fixed jaw is equipped with a main scale, while in the sliding jaw there is a nonius scale or a vernier scale. The nonius scale has a length of $10 \mathrm{~mm}$ which is divided into 10 scales with an accuracy of $0.1 \mathrm{~mm}$. In Surah Al-Qamar verse 49 Allah Swt says:

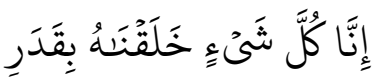

Meaning: "Indeed We created everything according to a measure." (Surat al-Qamar: 49). In Surah Al-Furqan verse 2 Allah Swt says:

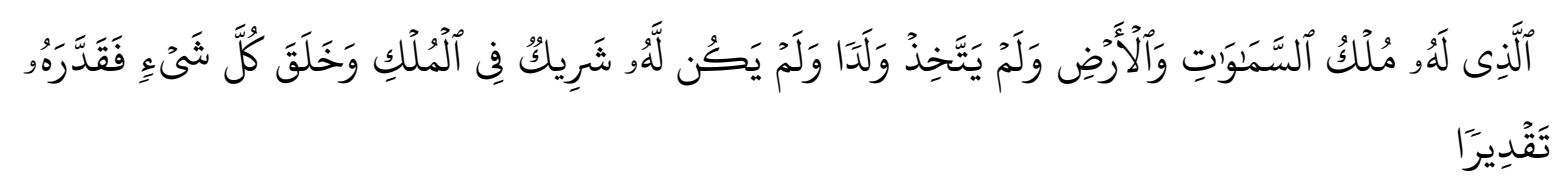

Meaning: "To Him belongs the kingdom of the heavens and the earth, and He has no children, and He has no partner in (His) power, and He has created all things, and He has set their measurements as neatly as possible. ." (Surat al-Furqan: 2). The verse above explains to humans about measurement, namely what is in nature can be expressed in two roles, the first as a number with the nature and accuracy contained therein and the second as a law or rule.

\section{Quranic Verses about Waves}

Waves are transverse waves applied in everyday life, such as radar, gamma rays, and Xrays which are useful in the fields of science and medicine. Radar (Radio Detection and Ranging) emits light waves with the principle of light reflection. Radar is a system of tools to detect the presence, location, speed, and direction of motion of objects in the distance, such as airplanes and ships, through the ability of these objects to reflect a beam of electromagnetic radiation 
with a wavelength of several centimeters. Radar is also used for navigation and scouting. The device system consists of a transmitter which produces radio frequency radiation, often in the form of pulses, which is fed to a movable antenna which is then emitted as a radiation beam. When the beam is disturbed by a solid object, some of the radiant energy will be reflected back to the antenna. The signal received by the antenna is passed on to a receiver, which then amplifies and detects it. The echo from the reflected solid is indicated by a sudden rise in the detector output. The time it takes for the pulse to reach an object and to be reflected back.

Gamma rays are electromagnetic radiation that radiates from the atomic nucleus with very high energy. Gamma rays have a frequency between $10^{20} \mathrm{~Hz}$ with a wavelength between $10^{-11} \mathrm{~cm}$ to $10^{-8} \mathrm{~cm}$. Its penetrating power is so great that it can penetrate lead plates and iron plates which are several $\mathrm{cm}$ thick. Gamma rays are widely used in the fields of science and medicine. In science, gamma rays are used to aid the study of nuclear physics and astronomy. In the field of medicine, gamma rays are used for the diagnosis and therapy of cancer. Currently, the application of gamma rays for disinfection and food preservation is being developed.

X-rays were discovered in 1895 by Wilhelm K Rontgen, also called X-rays. X-rays have a frequency between $10^{16} \mathrm{~Hz}$ to $10^{20} \mathrm{~Hz}$. The wavelength is very short, i.e. $10^{-9} \mathrm{~cm}-10^{-6} \mathrm{~cm}$. Because the wavelength is very short $\mathrm{X}$-rays have a strong penetrating power. X-rays can penetrate soft objects such as flesh and skin, but cannot penetrate hard objects such as nose, teeth, and metal. Because of this, these rays are often used in the medical field, especially to see conditions in the body without performing surgery. X-ray photos are taken using an X-ray camera. The hard parts of the body will block the X-rays so they emit a fluorescent light on the film.

In addition to the medical field, $\mathrm{X}$-rays are also used to detect objects. At airports, hotels and shopping malls to check the goods carried by visitors or passengers. X-rays are also used in radiographic techniques to examine an object and check for damage or defects in machinery. $\mathrm{X}$-rays are also often used to examine crystal structures. In Surah Ar-Rum verse 46 Allah says:

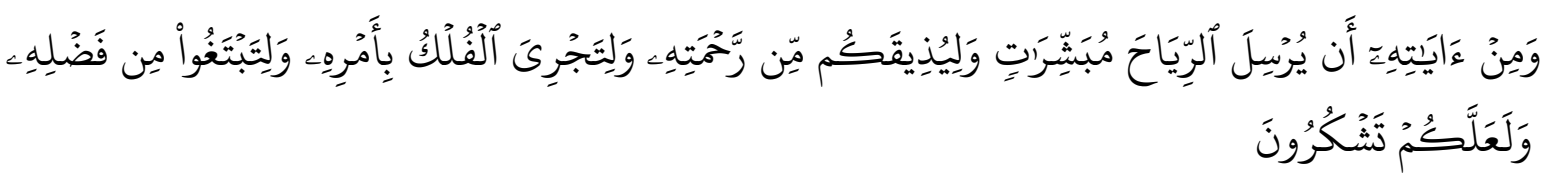

Meaning: "And among the signs of His power is that He sends the wind as a bearer of glad tidings and to taste for you some of His mercy and so that ships can sail by His command and (also) so that you may seek His bounty; I hope you are grateful." (Surat Ar-Rum: 46).

The verse above explains to humans about the measurement of waves here as the wind blows bringing clouds to send rain water and the wind blows the sails so that they can sail in the sea. We feel the closeness of the meaning of "wind" in this verse is a wave, not only sound waves that carry news but also radio waves or electromagnetic waves that can be emitted to all corners of the world.

\section{Quranic Verses about Dynamic Fluids}

A fluid is a substance, either a liquid or a gas, that can flow. A fluid is said to be flowing if it is in constant motion with respect to its surroundings. Fluids consist of static and dynamic fluids. Static fluid has the characteristics of compressed, not steady, and viscous flow. Meanwhile, dynamic fluids have characteristics such as having incompressible flow (no change in volume when pressure is applied), steady (the velocity of fluid flow at a point is constant with time), and not viscous (fluid flow does not experience friction due to the nature of the fluid). the viscosity of the fluid). 
Dynamic fluids have many uses that can be applied in everyday life. One example of the application of dynamic fluids is the lift force on an airplane. The lift in an airplane is defined by Bernoulli's law. Engines on airplanes provide thrust so that the aircraft can move forward. Meanwhile, the wings on an airplane provide the lift needed for the airplane to fly. In the laws of physics, objects always fall towards the center of the earth because of the gravitational force acting on each object. However, there is also an upward force that is vectorically opposite to the gravitational force. These two forces are used as factors that make airplanes fly.

Airplanes can be lifted into the air because of the speed of air passing through the wings of the aircraft. Airplanes are not like rockets which are lifted upwards because of the actionreaction forces between the gases that are ejected by the rocket itself. The rocket shoots gas backwards and as a reaction the gas pushes the rocket forward so that the rocket can be lifted up even though there is no air, but an airplane cannot lift if there is no air.

The top of the airplane wing is made more curved than the bottom of the airplane wing. Fluid flowing on the surface of a curved object will tend to follow the curved shape of the object before continuing its journey even though it will eventually distort the direction of the fluid velocity. This causes when the aircraft is moved forward, the airflow rate at the top of the airplane's wings will be faster than the airflow rate at the bottom of the aircraft. The travel time (t) of air flow in both halves is the same while the length of the path (s) that the air travels at the top is longer than the path length at the bottom of the aircraft. Since the air velocity at the top of the wing is faster than the air velocity at the bottom of the wing, the air pressure above the wing is less than the air pressure at the bottom of the wing.

This is in accordance with Bernoulli's Law which is based on the law of conservation of energy experienced by fluid flow. Bernoulli's law states that the plane's lifting force (the plane pushing up minus the plane pushing down) is equal to the result of reducing the pressure on the bottom side with the pressure on the top side then multiplied by the cross-sectional area of the wing, or it can be abbreviated $F_{1}-F_{2}=\left(\rho_{1}-\rho_{2}\right)$ A. The lift equation can also be expressed by an equation, namely $F_{1}-F_{2}=\left(v_{2}^{2}-v_{1}^{2}\right) A$, or also called half of the density multiplied by the square of the change in velocity and multiplied by the cross-sectional area. An airplane can take off if the lift force is greater than the weight of the aircraft, where $F_{1}-F_{2}>m g$. Meanwhile, if the aircraft is at a certain altitude and that altitude is to be maintained, then the speed of the aircraft must be adjusted so that the lift is equal to the weight of the aircraft, namely $F_{1}-F_{2}=$ $\mathrm{mg}$, so that the aircraft does not move up or down.

The size of the lift depends on the size of the aircraft's speed from the engine thrust. The greater the speed of the aircraft, the faster the airspeed, where the result of reducing the square of the speed under the wing with the square of the speed above the wing increases, so that the lift force is faster. In addition, the lifting force is also influenced by the size of the wings or the cross-sectional area. The larger the cross-sectional area, the greater the lifting force.

In addition, there are several forces acting on an airplane as it hovers in the air. These forces include gravity, lifting force, forward force, and drag force. Lift must be able to overcome gravity while the thrust must be able to overcome drag so that the aircraft can fly. Gravity is the force caused by the Earth's gravity. Lift is caused by the shape of the plane. Lifting force depends on the position of the wing of the aircraft, so the position of the wing on the fuselage of the aircraft needs to be considered. The forward force is the force caused by the aircraft engine.

The drag force is the force caused by air friction. The drag force is divided into several, including form drag, skin friction drag, and induced drag. The drag form is a form of obstacle that arises because of the physical shape of the object with different coefficients depending on the object. On the plane, a streamlined shape is used so that the drag coefficient that arises is $5 \%$. Skin friction drag is the drag force that arises due to air friction with the surface of the 
object. The fuselage is made smooth to reduce drag. Induced drag is the drag that arises because of the lift. In Surah Al-Jasiyah verse 5 Allah Swt says:

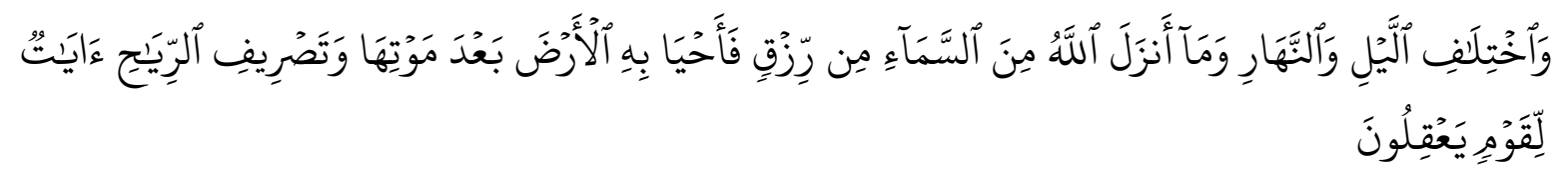

Meaning: "And at the alternation of the night and the day and the rain that Allah sends down from the sky and then He brings to life with it the earth after its death; and in the course of the winds are signs (of Allah's power) for a people of understanding." (Surat al-Jasiyah: 5). In Surah Al-Jasiyah verse 13 Allah Swt says:

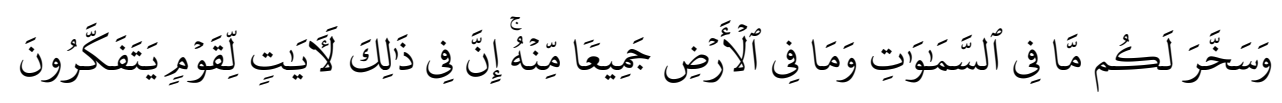

Meaning: "And He has subjected to you all that is in the heavens and what is on earth, (as a mercy) from Him. Verily in that there are indeed signs (of Allah's power) for a people who think." (Surat al-Jasiyah: 13).

The verse above explains to humans about fluids, which are closely related to air technology. Beginning with verse 5, with the translation as the wind range we are led to study the nature of fluids in motion or flow. Continued by paragraph 13, confirms the basis of air technology.

\section{Conclusion}

Al-Qur'an is a way of life for all mankind. The Qur'an is like a miniature of the universe that contains all scientific disciplines, and is a means of solving all problems throughout human life. The Qur'an encourages the study of science itself. Until now, there is not a single verse of the Qur'an that contradicts the facts of the latest science. The Qur'an is not a book of doubts. Many statements from the Qur'an have been proven and are known fact by most people today. The Qur'an is an undeniable truth. Physics has a very large and significant function and role for the existence of mankind. Humans can make various kinds of objects and equipment that can complement and facilitate human life itself because of the application of physics which is implied in sophisticated technology. That is, the development of equipment developed by humans is based on physics. The role of this physical science can ease the difficulties experienced by lightening the work of humans is not difficult. So it can be concluded that people should understand at least basic physics which has many benefits to alleviate various problems that occur in people's lives.

\section{References}

\section{Books}

Abdullah, M. A. (2014). Merajut Paradigma Filsafat Islam Keindonesiaan: Fresh Ijtihad Memperjumpakan Ulum al-din dan Sains Modern dalam Keilmuan Keagamaan Islam Filsafat Islam dan Pembangunan Bangsa. Bandung: Mizan

al-Al-Attas, S. M. N., Muzani, S., \& Baqir, Z. A. M. (1995). Islam dan Filsafat Sains. Bandung: Mizan.

Attas, N. (1995). Islam dan Filsafat Sains, terj. In Zainal Abidin. Bandung: Mizan.

Bakar, O. (1994). Esei-esei tentang Sejarah Filsafat Sains Islam. Bandung: Pustaka Hidayah. 
Gade, S. (2020). Integrasi Keilmuan Sains \& Islam. Ar-Raniry Press.

Husaini, A. (2020). Filsafat Ilmu: Perspektif Barat \& Islam. books.google.com.

Jamin, A., \& Ohira, N. (2016). Filsafat Ilmu: Telaab Pengetahuan, Ilmu dan Sains dalam Studi Islam. Alfabeta: Bandung.

Malik, A. W. (2013). Filsafat Ilmu dan Sains Prespektif Islam. Makassar: Alauddin University Press.

Naquib, A. (1995). Islam dan Filsafat Sains. Bandung: Mizan.

Salamuddin, S. (2020). Filsafat Sains Islam. Bandung: Kencana.

Soleh, A. K. (2018). Epistemologi Islam: integrasi agama, filsafat, dan sains dalam perspektif Al-Farabi dan Ibnu Rusyd. Ar-Ruzz Media.

Tipler, P. (1998). Fisika Untuk. Sains Dan Teknik. Jakarta: Erlangga.

\section{Journal}

Alfi, L. A. (2018). Konsep Ilmu Menurut Syed Muhammad Naquib Al-Attas (Analisis Buku Islam dan Filsafat Sains). Tasfiyah: Jurnal Pemikiran Islam, 2 (2), 195-209. doi: 10.21111/tasfiyah.v2i2.2580

Arif, M. (2016). Filsafat Sains Dalam Perspektif Pemikiran Islam. In Jurnal Program Pascasarjana Universitas Islam Negeri Sumatera Utara

Bakuwa, Y. (2013). Urgensi Sains Fisika dalam Perspektif Al-Qur'an. Skripsi. https://repository.ung.ac.id/skripsi/show/421408091/urgensi-sains-fisika-dalamperspektif-al-quran.html

Ediyanto, Atika, iva nandya, \& ardiana pangestika konita. (2019). Fisika dan Analoginya dalam Kehidupan. Yayasan Pusat Pendidikan Angstrom. Retrieved from https://educationcenter.id/ace-press/index.php/ojs/article/view/2

Habibi, A. (2020). Diskursus Etika Aristoteles dalam Islam. Mawa'iz̧: Jurnal Dakwah Dan Pengembangan Sosial Kemanusiaan, 11 (1), 97-122. https://doi.org/10.32923/maw.v11i1.1021

Hadi, S., \& Ashari, A. (2020). Mendudukkan Kembali Makna Ilmu dan Sains dalam Islam. Tasfiyah: Jurnal Pemikiran Islam, Unida Gontor, 4 (1), 27-45. doi: http://dx.doi.org/10.21111/tasfiyah.v4i1.3963

Hamzah, M., \& Muniroh, B. (n.d.). Konsep Gaya Tarik (Gravitasi) Dalam Perspektif Al-Qur'an Dan Sains (Kajian Surat Al-Hajj Ayat 65. SPEKTA: Jurnal Kajian Pendidikan Sains. 2 (2), 146-168. doi: http://dx.doi.org/10.32699/spektra.v2i2.13

Huda, M., \& Mutia, M. (2017). Mengenal Matematika dalam Perspektif Islam. FOKUS Jurnal Kajian Keislaman Dan Kemasyarakatan, 2(2), 182. https://doi.org/10.29240/jf.v2i2.310

Isgandi, Y. (2021). Model Integrasi Nilai Islam Dan Sains Beserta Implementasinya Di Dunia Islam. Kalimab: Jurnal Studi Agama Dan Pemikiran Islam, 19 (1), 27-48. DOI: http://dx.doi.org/10.21111/klm.v19i1.6364

Laurenty, F., Rahmad, M., \& Yennita. (2018). Application of Learning by Science Integration and Religion Approach to Increase Students Motivation Physics Learning. Physics Education Study Program University of Rian University of Rian, 1-9.

Lazuardy, A. Q., \& Lestari, P. A. (2021). ADAB PENGAJARAN SAINS DALAM ISLAM. Prosiding Konferensi Integrasi Interkoneksi Islam Dan Sains, 3, 156-170. Retrieved from http://sunankalijaga.org/prosiding/index.php/kiiis/article/view/728 
Masruri, S. (2018). Piramida Integrasi Keilmuan Islam dan Sains. Prosiding Konferensi Integrasi Interkoneksi Islam Dan Sains, 1, xiii. Retrieved from http:// sunankalijaga.org/prosiding/index.php/kiiis/article/view/37

Muin, F. (2015). Konvergensi Islam dan Sains Dalam Perspektif Filsafat. MIQOT: Jurnal Ilmuilmu Keislaman. XXXIX (2), 241-254.

Nasution, M. A. (2016). Filsafat sains dalam perspektif pemikiran Islam. Universitas Islam Negeri Sumatera Utara. https://core.ac.uk/download/pdf/266977051.pdf

Noor, F. M. (2012). Integrasi-interkoneksi Keilmuan Sains dan Islam dalam proses Pembelajaran Fisika. Seminar Nasional Fisika Dan Pendidikan Fisika. 3 (4), 303-312. https://jurnal.fkip.uns.ac.id/index.php/prosfis1/article/view/3761

Nova, V. C. S. (2021). Telaah Epistemologi Integrasi Sains Dan Agama Di Perguruan Tinggi. repository.radenintan.ac.id. http://repository.radenintan.ac.id/id/eprint/13210

Parhan, M., \& Kurniawan, D. P. D. (2020). Aktualisasi Peran Ibu Sebagai Madrasah Pertama Dan Utama Bagi Anak Di Era 4.0. JMIE (Journal of Madrasah Ibtidaiyah Education), 4(2), 157. https://doi.org/10.32934/jmie.v4i2.193

Pradhana, A., \& Sutoyo, Y. (2019). Worldview Islam sebagai Basis Pengembangan Ilmu Fisika. TSAQAFAH: Jurnal Peradaban Islam, $15 \quad$ (2), 187-214. DOI: http://dx.doi.org/10.21111/tsaqafah.v15i2.3387

Putra, D. S., Lumbantoruan, A., \& Samosir, S. C. (2019). Deskripsi Sikap Siswa: Adopsi Sikap Ilmiah, Ketertarikan Memperbanyak Waktu Belajar Fisika dan Ketertarikan Berkarir di Bidang Fisika. Tarbiyah: Jurnal Ilmiah Kependidikan, 8(2), 91. https://doi.org/10.18592/tarbiyah.v8i2.3339

Rahayu, W. S. (1997). Tinjaun filsafat sains dalam perspektif Islam. Undergraduate thesis, IAIN Sunan Ampel Surabaya. digilib.uinsby.ac.id. http://digilib.uinsby.ac.id/43850/3/Wiwik Sri Rahayu_059210132.pdf

Ridwan, I. M. (2020). Harmoni, Disharmoni, dan Integrasi Antara Sains dan Agama. Jurnal Filsafat Indonesia. 3 (1), 8-13. DOI:10.23887/jfi.v3i1.22472

Sangadah, F. (2019). Efektivitas penggunaan modul fisika materi momentum dan impuls berpendekatan integrasi sains dan Islam terhadap hasil belajar siswa. eprints.walisongo.ac.id. http://eprints.walisongo.ac.id/10420/

Sihabussalam, S. (2020). Diskursus Islam dan Sains dalam Peradaban Masyarakat Menuju Kaum Wasathiyah. Prosiding Konferensi Integrasi Interkoneksi Islam Dan Sains, 2, 35-39. Retrieved from http://sunankalijaga.org/prosiding/index.php/kiiis/article/view/369

Usuluddin, W. (2016). Potret Kontestasi Filsafat Islam dalam Era Sains Modern. Al-Tabrir: Jurnal Pemikiran Islam. 12 (2), 259-277. DOI : 10.21154/al-tahrir.v12i2.57

Wati, L., Rahimah, R., Nengsih, E. W., \& Mardaya, M. (2021). Media Pembelajaran Majalah Fisika Terintegrasi Nilai KeIslaman. Jurnal Ilmiah Pendidikan Fisika, 5(2), 195-203. https://doi.org/10.20527/jipf.v5i2.2731

Zain, Z., \& Vebrianto, R. (2017). Integrasi keilmuan sains dan islam dalam proses pembelajaran rumpun IPA. Seminar Nasional Teknologi Informasi komunikasi dan Industri http://ejournal.uin-suska.ac.id/index.php/SNTIKI/article/view/3198 